\title{
Satisfaction and retention strategies for Nigerian Generation Y customers
}

\author{
Edmund Ehichioya Otaigbe* and Christopher Beehner \\ College of Management and Technology, Walden University, Minnesota, USA.
}

Received 1 July, 2019; Accepted 5 August, 2019

\begin{abstract}
Firms in the service industry have experienced a 15 to $30 \%$ drop in customer satisfaction ratings estimated at $\$ 10$ billion annually due to the unpredictable tendencies of Generation $Y$ customers, also known as Millennials. Researchers project that the population size, spending power and inconsistent behavioral pattern of this generational cohort might determine how customers will relate to service providers in the future. The purpose of this multiple case study was to explore the customer satisfaction strategies business leaders use to retain Generation $Y$ customers in Nigeria. The target population consisted of 3 business leaders from the service industry in Akwa Ibom State, Nigeria, who have successfully retained Generation Y customers. The theory of customer satisfaction management system served as the study's conceptual framework. Data collection was through semistructured interviews and the company's archived documents. Patterns were identified through data familiarization, data coding, and theme development and revision. Interpretations were subjected to methodological triangulation and member checking to ensure the trustworthiness of the findings. The themes that emerged from the study were: Positive brand image creation, social media as an enabler, and quality service and timely delivery.
\end{abstract}

Key words: Generation Y, customer satisfaction, loyalty, retention, engagement, millennial.

\section{INTRODUCTION}

The coming of age of the largest and fastest growing generational cohort, Generation $\mathrm{Y}$, is reshaping the business landscape of the 21st century (Bolton et al., 2013). With more than $25 \%$ of the world's population and a spending power estimated at $\$ 34$ trillion, members of the Generation $Y$ cohort have emerged as an economically robust cluster (Bilgihan, 2016). In the United States, Generation Y members constitute $27 \%$ of the country's population, and the annual spending of this group grew from $\$ 97.3$ million in 2003 to $\$ 200$ billion in 2015 (Bowen and Chen McCain, 2015). Despite the increased disposable income, Generation $Y$ consumers are more unpredictable than their predecessors, Generation $X$ and baby boomers (Amin, 2016; Kandampully et al., 2015). Parment (2013) noted that the inconsistent behavior of the members of Generation $Y$ cohort might determine how customers will relate to service providers in the future. 
Customer satisfaction refers to the sum of a customer's experiences with a firm (Gizaw and Pagidimarri, 2014). A lack of customer satisfaction (also called dissatisfaction) can adversely affect the revenues of a company because most businesses depend on steadily increasing customer patronage (Chuah et al., 2017). Social media, customer perceived value, co-creation, brand ambassador, customer engagement, and customer communities are some of the emerging concepts describing customers' new mindsets that business leaders now seek to understand and exploit to gain traction (Kandampully et al., 2015).

As the business landscape becomes increasingly dynamic and competitive, several researchers have found a positive relationship between service quality (Choudhury, 2014), customer satisfaction (Kaura, 2013), customer loyalty (Chodzaza and Gombachika, 2013), and firm performance (Choudhury, 2014). However, there is little information about how the emerging concepts relate to Nigerian Generation $\mathrm{Y}$ customers. In Nigeria, the failure of business leaders to satisfy their customers has led to a loss of revenue (Adebayo, 2013). Therefore, the ability of business leaders to satisfy Generation $Y$ consumers is a significant decision for business success and long-term profitability (Kandampully et al., 2015). The purpose of this qualitative multiple case study was to explore customer satisfaction strategies use by business leaders to retain Generation Y customers. The general business problem is the failure of some business leaders in the service industry to satisfy their customers, which has led to a loss of revenue in the industry. The specific business problem is that some business leaders lack customer satisfaction strategies to retain Generation $Y$ customers.

\section{LITERATURE REVIEW}

\section{Customer satisfaction management system}

Kobylanski and Pawlowska (2012) developed the customer satisfaction management system (CSMS) in 2012 to advance a more robust framework for understanding customer satisfaction. While previous researchers emphasized one-dimensional benefits of customer satisfaction, Kobylanski and Pawlowska (2012) posited that customer satisfaction management must extend beyond improving these effects. The CSMS theory involves using a strategic and systematic approach to customer satisfaction that incorporates continuous improvement for businesses (Kobylanski and Pawlowska, 2012).

CSMS is useful in measuring the value of a strategic focus on customer satisfaction that might result in a competitive advantage for business sustainability (Gizaw and Pagidimarri, 2014). Kobylanski and Pawlowska
(2012) argued that the focus of CSMS involves (a) repositioning and enhancing brand image, (b) enriching an organization's reputation, and (c) preserving the future value of a business. Kobylanski and Pawlowska (2012) also identified other factors that enhance customers' satisfaction as (a) increase in stock price, (b) increasing the credibility of new products development, and (c) examining the reality of a connection with stakeholder return. Understanding and realigning a pattern of customer behavior based on customer satisfaction levels may assist in identifying and managing customers' changing needs.

\section{Generation $Y$ purchase behavior}

Generation $Y$ refers to individuals born between 1980 and 2000 (Donnelly and Scaff, 2013). Generation Y individuals are the children of baby boomers and the younger siblings of Generation X (Ordun, 2015; Schewe et al., 2013). Another term often used to refer to Generation $Y$ members is millennials, because some members of the generation reached young adulthood at the birth of the new millennium (Debevec et al., 2013). The attributes of generational cohorts are distinct regarding their preferences, values, and shopping behaviors (Lissitsa and Kol, 2016; Toldos-Romero and Orozco-Gómez, 2015). Generation Y consumers do not trust brands and advertisements but rely on the reviews and comments from their peers in the social media (Sasmita and Suki, 2015). Anselmsson et al. (2014) related the concept of brand image to the consumer's use of a product or service to reflect some symbolic meaning of the consumption and identity in self-expression. The implication is that Generation Y consumers may be more willing to relate with brands that have positive reviews from peers on social media platforms as a form of generational identity. The impact of social media may be useful in predicting future behavioral patterns of Generation Y consumers (Bolton et al., 2013).

\section{The Nigerian millennial}

By 2050, Nigeria is projected to becoming the world's fourth most populous country with a population size of 392 million from 186 million in 2016 (World Factbook, 2016). The country's current median age of 18.4 years and high population birth rate are indicators of the burgeoning population of Generation $Y$ individuals. With over 144 million mobile phone subscriptions, 76 out of every 100 inhabitants have a mobile phone (World Factbook, 2016). In a related study, up to three-quarters of Generation $Y$ individuals have created their profiles on social media platforms. Millennials in Nigeria, like their contemporaries in North America and Western Europe 
are also fusing their social lives into technology (Counted and Arawoye, 2016). Although the term millennial as applied in Western countries may not be a perfect fit with the young social generation in Nigeria, however being connected to the internet, a hunger for information and change, and reliance on social media describes some of their similar characteristics with millennials in general (Kolawole, 2017).

\section{Customer engagement through satisfaction}

Customer engagement plays a central role in customer relationships, and fits into strategies for continuous improvement of customer satisfaction (Ashley and Tuten, 2015). The combination of constant engagement approaches with technology has resulted in Generation $Y$ customers that are more informed, empowered, interconnected, rarely loyal, and more demanding of active roles in the conceptualization of product and services (Straker and Wrigley, 2016). The negative effects of customer engagement include (a) customers' dissociation from an object, (b) customers organizing public action against an organization, or (c) customers delivering negative word-of-mouth publicity (Brodie et al., 2011; Verleye et al., 2016). Business leaders are now adopting strategies to pay attention to nonpurchase customer behaviors because of their influence on satisfaction and lifetime value (Maslowska et al., 2016).

\section{Customer satisfaction through loyalty programs}

Considering the growing dominance of Generation $Y$ consumers in the market space, Bowen and Chen McCain (2015) revealed that existing loyalty models designed for baby boomers were unsuitable for Generation $Y$ consumers. The researchers proffered that ideal models for Generation Y should include (a) instant reward, (b) apps to easily access the products, (c) a platform on the app and social media to receive customer input, (d) social responsibility initiatives relevant to Generation Y cohort, and (e) platforms that enhance social interaction in public areas (Melnyk, 2014; Melnyk and Bijmolt, 2015). Some of the issues limiting the usefulness of loyalty programs include (a) cost concerns in administering loyalty programs by firms, (b) low levels of consumer commitment, (c) apathy due to challenges faced by users in claiming rewards, and (d) the shortlived benefits of loyalty programs due to competition (Xie and Chen, 2013).

\section{Gap in literature to improve business}

Gizaw and Pagidimarri (2014) evaluated the CSMS in measuring the value of a strategic focus on customer satisfaction in sustaining business objectives and mission. Other researchers appraised customer satisfaction as a tool for improving organizational competitiveness and productivity in firms (Alvarez-Garcia et al., 2017). Munari et al. (2013) examined customer satisfaction focusing on identifying the quality of service that could influence client perception. However, despite previous studies on customer satisfaction strategies, none seem to have revealed customer satisfaction strategies specific to Nigerian Generation Y customers.

\section{MATERIALS AND METHODS}

\section{Population and sampling}

The population for this study included business leaders from the service industry in Nigeria who are responsible for the formulation and implementation of business strategies for customer satisfaction and retention. Three participants who are leaders with experiences drawn from various segments of the service industry were selected for the study. A relatively small sample size is adequate for a case study design because the focus is not on the size of the sample, but the richness of the data gained from the in-depth insights of the phenomenon shared by the participants in the study (Yin, 2014). Purposive sampling was used to identify participants who met the criteria for the study, which were consistent growth in the retail customer base and profitability. These criteria are likely indicators that the leaders of the companies have a successful business strategy for retail customer acquisition, customer satisfaction, and retention.

\section{Data collection instruments}

Semi-structured interview protocol and document review were used as data collection methods. A semi-structured interview protocol is necessary when using the multiple case study design (Rossetto, 2014). Collecting data through semistructured face-to-face interviews allows participants to describe and elaborate on individual experiences thereby enhancing the richness of the data through the discovery of new themes (Price et al., 2015). After the interviews, we transcribed the responses and communicated directly with participants to clarify, validate, and confirm the accuracy of the data collected. We used member checking to ensure credibility of the research. The use of archival documents was used to triangulate all data through convergence to make meaningful information and ensure the reliability and validity of the research study. We also reviewed the companies' business strategy from the public domain to have an in-depth understanding of the strategies used by leaders.

\section{Data collection technique}

The semi-structured interview process commenced with scheduling meetings with participants that have signed the informed consent form. We followed an interview protocol and asked the same questions to all three participants to ensure validity and reliability of the study. The format of the questions for the interviews was openended to encourage dialogue and urge participants to provide more insights into the phenomenon (Rossetto, 2014). The comparison of 
archival documents on customer satisfaction and interview findings were essential to addressing the research question. The archival documents included annual reports, organization's website, and any other relevant data in the public domain.

\section{Data analysis}

Methodological triangulation was used for this study, comparing the themes and patterns from the interview transcript data with the archival document to identify convergent data. The use of NVivo software to organize the data assisted in managing large amounts of narrative data and enhanced the accuracy of the analysis. The last step of data analysis involved a scrutiny of the data and descriptions through a review of the codes drawing from CSMS theory, the research question, and extant literature.

\section{RESULTS AND DISCUSSION}

\section{Theme 1: Positive brand image creation}

The first theme that emerged from the analyzed data was positive brand image creation, with all participants agreeing on the importance of creating a positive brand image to retain Generation $Y$ customers. The three participants mentioned that Generation $Y$ customers are comfortable with brands that they trust. ED1A1 emphasized the importance of creating a positive brand image and how Generation $Y$ customers identified with brands that were trendy and dependable. Likewise, ED1A3 noted that the process of creating a positive brand image helped in positioning their company within the younger generation of customers. ED1A2 inferred that young people are attracted to positively looking visual images, and are concerned about how products are packaged and presented because it boosts their selfimage.

ED1A1, ED1A2, and ED1A3 fostered their brands through the combination of physical and virtual brand elements such as product features, package features, service quality, ambience, color schemes, promotional items, nature of facilities, and website content to create desired positive impressions in the minds of Generation $Y$ customers. ED1A2 explained that they focused on the color schemes, package features, and ambience because they observed that Generation $Y$ customers preferred to relate to brands that could help boost their identity or self-esteem. Likewise, ED1A3, noted that the deliberate fine-tuning of their brand image included the choice of the product label and features, color schemes, office branding, and website content to position the company and retain Generation $Y$ customers. The participants' assertions align with the findings of Rudawska (2014) who revealed that $90 \%$ of Generation $Y$ customers have an emotional attitude toward brands.

To execute the strategy of creating a positive brand image, ED1A2 reported having engaged a brand expert to ensure the company optimized the benefits of branding to Generation Y. ED1A3, commented that the organization implemented key changes including realignment of the organizational structure, remodeling of branch offices, and redesigning of products, which helped in creating a positive brand image and retaining Generation $Y$ customers. The impact of creating a positive brand image was effective in retaining Generation $Y$ customers, as reported by the participants. ED1A1, highlighted an ease in connecting with Generation $Y$ customers who enthusiastically accepted and flaunted the organization's promotional items. ED1A2 stated that Generation $Y$ customers were not only impressed with the company's packaging but also proudly identified with the brand and willingly referred the company to their peers. Likewise, ED1A3, stated that during their product campaigns at campuses, many students signed up and some students even offered to enlist as brand ambassadors for their organization at no cost. The findings align with Saaksjarui et al. (2016) suggestion that the positive attributes of a brand image significantly influence Generation $Y$ customer's perception of the products and the organization.

The analysis of the participating companies' corporate strategy based on information available on the websites, and 2016 audited financial reports revealed statements such as "creating an enduring brand that would outlive generations," "high-quality brand," "positive image," and "next generation products." Words used to describe the brand logo include "distinctive, simple, elegant, vibrant, memorable, energy, bold, innovativeness, and excitement." The information from the aforementioned sources suggests that the companies' strategies were aimed at creating visibility among Generation $Y$ customers by projecting a positive brand image that was trendy, youthful, vibrant, and reliable. Although the information did not indicate if the strategy was exclusively for Generation $Y$ customers or to the broad category of youths, the participants explained that Generation $Y$ customers were an intrinsic part of the customer satisfaction and retention strategy. The explanation was that Generation $Y$ customers were the legally eligible working class among the youths because they currently (2018) fall within the age range of 18 to 38 years.

The participants' views on creating a positive brand image concurred with several findings from the literature review. Chinomona (2016) stated that positive brand image is the consumer's mental picture of the offering of a firm's product or services, which includes symbolic meanings that consumers associate with the specific attributes of the product or services. Ordun (2015) identified factors such as the trend; prestige, brand, and excellent service are some elements of positive brand images that influence the decisions of members of Generation Y cohort. Chen et al. (2016) stated that Generation $Y$ customers often based their decision to buy 
a product on the positive image of the brand.

\section{Theme 2: Social media as an enabler of generation $Y$ customer satisfaction}

The second theme that emerged was social media as an enabler of Generation Y customer satisfaction. All three participants affirmed that with social media, they had gained access to Generation $Y$ customers who are techsavvy and often described as digital natives. The participants explained that, as an enabler, social media platforms facilitated effective communication and helped build trust with Generation Y customers. The participants also noted that social media was useful for assessing Generation $Y$ customers' satisfaction with the organization's products and services. ED1A3, explained that the social media platform supported continuous business improvement and collaboration with Generation $Y$ customers. ED1A2 also underscored the importance of social media platforms, and remarked: "Using the social media has been undoubtedly very helpful in gauging the performance of our products and services, and staying close to Generation Y customers." This component of the theme supports findings of Tsimonis and Dimitriadis (2014) that businesses use social media to prize competition, announce new products and services, interact with clients, provide advice to clients, and provides useful information to resolve customer service issues.

The participants explained that the use of social media supported direct means of communication and provided a platform that encouraged the involvement and participation of Generation $Y$ customers. ED1A3, explained that the social media platform was useful in anticipating Generation $Y$ customer's experience, provided access to a broader pool of customers, and served as a guide in the development of products and services. Furthermore, ED1A1 noted: "...using the social media has been undoubtedly very helpful in engaging Generation $Y$ customers and marketing..." The findings in this theme reinforce the work of Lissitsa and Kol (2016), who noted information technology (social media) as a viable platform to connect with Generation $Y$ customers.

A review of the websites to determine what social media platforms the participants' organization use revealed that Facebook was common to all participants' companies. The website of ED1A1, had the most social media platforms such as Facebook, Twitter, Instagram, Google Plus, Linkedln, and YouTube while the website of ED1A2 had only Facebook. The participants also noted that because interaction on their organization's online live chat menu was low, they had to explore other social media platforms to gain access to Generation $Y$ customers.

The participants differed slightly in their social media strategies and the degree of reliance. For example, ED1A2 reported that the organization's focus is to receive customer feedback, stating "we regularly get feedback from our target market (Millennials) which enables us to adjust our processes to fit their needs." ED1A1 and ED1A3, noted that Instagram, Twitter, and Facebook were very helpful in engaging Generation $Y$ customers and promoting sales. ED1A3 commented that the use of social media allowed for innovation, improved communication, and referral from Generation $Y$ customers. ED1A3 underscores Floreddu and Cabiddu's (2016) finding by attributing their organization's success in retaining Generation $Y$ customers to the use of social media in projecting their brand, taking their services to a wider pool of customers, and creating the necessary platform for interaction that boosted customer patronage.

The participants' views on social media as an enabler of Generation $Y$ customer satisfaction concurred with the findings of Floreddu and Cabiddu (2016), who identified benefits of using social media to be: facilitation of relationship building with clients, broader customer access, brand awareness, and increased sales. Arnaboldi et al. (2017) also revealed that the interaction between clients and firms through social media platforms lead to an enhanced relationship with customers, brand awareness, and increased customer engagement. In addition, statements of the business strategy found on the companies' websites such as "developing products with the help of stakeholders in dialogue," and "making a deliberate effort to understand target customers intimately" indicates a strategy aimed at improving customer interaction. The participants also highlighted some prominent subthemes resulting from the use of social media: (a) continuous engagement, (b) feedback, and (c) co-creation.

\section{Continuous engagement}

The study participants revealed that continuous engagement fostered satisfaction and retention of Generation $Y$ customers, because Generation $Y$ customers were inclined to be fickle and impatient. ED1A2 explained that Generation Y customers could easily "dump" a brand or product impulsively; without any consultation, complaint or feedback. Likewise, ED1A3 stated, "These groups of people (Generation Y) are not particularly loyal. You constantly need to engage them to know what's on their minds, to understand their expectations and satisfy them." The participants' assertion aligns with Harwood and Garry's (2015) argument that customer engagement is useful in understanding and managing interactions between organizations and customers.

The participants differed slightly in their approaches to continuous engagement. ED1A1 used an experiential 
process comprising visual and verbal expressions in communication, and product affiliation to cast an impression in the mind of the target customers. ED1A3 explained that the process of continuous engagement involved conducting product awareness campaigns on school campuses, scheduling online live chat fora with customers, and encouraging Generation Y customers' feedback through social media platforms. ED1A3 further explained that relationships built through continuous engagement allowed for easy adoption, interaction, and more referrals from Generation $Y$ customers. The participants' views on the importance of continuous engagement to satisfying and retaining Generation $Y$ customers concurred with the findings of Maslowska et al. (2016), who revealed that customer engagement involves a dynamic set of interrelationships between the customer and an organization in an ecosystem facilitated by social media platforms.

The participants affirmed that continuous engagement was helpful in building relationships with Generation $Y$ customers, adding that the relationships improved as a result of increased customer involvement and participation through continuous engagement. This subtheme echoes the findings of Celuch et al. (2015) and Wepener and Boshoff (2015) that service-oriented organizations use continuous engagement as a tool for increasing customer involvement, and allowing customers to contribute to service improvement and customer satisfaction. Moreover, Naumann et al. (2017) suggested that engaged customers display higher levels of commitment, loyalty, and satisfaction.

\section{Feedback}

All three participants emphasized the importance of feedback in satisfying and retaining Generation $Y$ customers. ED1A2 noted that "customer feedback enabled the organization to identify areas to effect changes." ED1A1, reported Generation Y customers often provided feedback because they want products or services that suit their personality. All three participants noted feedback was useful in assessing the performance and quality of products and services. ED1A3 added that obtaining feedback from Generation Y customers through social media platforms was a continuous process. The participants agreed that customer feedback was helpful in projecting the organization as flexible and in tune with Generation $Y$ customers. The participants' views concerning the role of feedback in projecting organizational flexibility and attunement to Generation $Y$ customers supported the findings of Ashley and Tuten's (2015), who discovered customer feedback plays a central role in customer relationships and fits into strategies for continuous improvement of customer satisfaction in organizations.

The participants claimed the use of customer feedback helped in managing the perception of Generation $Y$ customers who would rather trust the reviews of peers on the social media platforms than authorized publications from organizations. The participants also noted that because the information reviewers shared on the social media platforms are not censored, feedback from customers may also potentially misinform, mislead, or create a wrong perception. The subtheme of feedback agrees with the findings of Jaakkola and Alexander (2014), who opined that customer's feedback, involves interactive customer relationships which may result in positive or negative feedbacks. The participants agreed that the process of managing customer perception through feedback included early detection of customers' concerns, prompt resolution of the complaints, and providing updates on all issues through the social media platforms.

\section{Co-creation}

ED1A1 and ED1A3 identified co-creation as essential for satisfying Generation $Y$ customers, describing cocreation as the process of getting customer input in the design of products or services. The participants suggested co-creation results in more acceptable products, and a sense of collective ownership and pride among Generation Y customers. The participants' views on co-creation supported the findings of Preikschas et al. (2017), who concluded that co-creation helps business leaders to place customers as co-owners, co-creators of value, brand advocates, and emotionally loyal customers.

Co-creation was fostered by encouraging collaboration with Generation $Y$ customers during engagement and feedback sessions. For example, ED1A3 stated, "we organized live sessions to talk about our products and encourage ideas from customers on improvements to make on existing products and identify opportunities for new products." Likewise, ED1A1 indicated that social media platform acts as an inclusion mechanism that facilitates collaboration with the Generation $Y$ customers in the design and development of products. The participants' assertions reinforced the findings of Straker and Wrigley (2016), who showed that organizations cocreate value through the intersection of people, business, and technology (social media).

The statements found on the companies' websites support a willingness to co-create with customers. Statements such as "developing products with the help of stakeholders," and "a desire to understand and partner with target customers intimately" indicates a strategy aimed at improving satisfaction through collaboration and co-creation with Generation $Y$ customers. The participants' discovered that collaborating with Generation $Y$ customers to co-create products and services requires patience, good listening, and flexibility to understand 
customer behavior. Price et al. (2015) confirmed that understanding customer behavior was beneficial to cocreating value.

\section{Theme 3: Quality service and timely delivery increased Generation Y customers' satisfaction}

The third theme that emerged was quality service and timely delivery increased Generation $Y$ customers' satisfaction. All participants agreed on the importance of quality service and timely delivery as critical to satisfying and retaining Generation $Y$ customers. All participants mentioned that Generation Y customers appreciate good quality products that organizations deliver promptly, noting that emphasis on quality service and timely delivery was necessary because Generation $Y$ customers are very knowledgeable about what they want, have a good taste for quality, and are fickle, and impatient. The participants' views on quality service and timely delivery supported the findings of Straker and Wrigley (2016), who concluded Generation $Y$ customers are more informed, interconnected, rarely loyal, and more demanding in the quality and speed of delivery of products and services than predecessor generations (Baby boomers and Generation X).

ED1A1 and ED1A2 explained that understanding of the behavioral attributes of Generation $Y$ customers influenced the steps taken to ensuring quality service and timely delivery. ED1A1, underscored this position by sharing from an experience of a dismal product launch where they introduced a product developed abroad by their sister company without customizing the product to fit the attributes and preferences of Generation $Y$ customers locally. Likewise, ED1A2 explained Generation Y customers are inclined to look beyond the attractiveness of promotional items or discounts but are more interested in the intrinsic value of a product and its delivery. The findings concur with the research by Guillet and Kucukusta (2016), who showed that understanding customer's behavior is relevant to delivering quality service to satisfy customers.

The participants described how quality service and timely delivery led to Generation Y customers' satisfaction and retention. ED1A3 explained that to ensure quality service and timely delivery they had to design simplified and less expensive products that customers could access online. Likewise, ED1A2 stated that extra care was taken to ensure the quality of products and service levels were consistent and prompt. Keisidou et al. (2013) revealed that service quality had strong connections with and serves as a substantial measure of customer satisfaction. Both ED1A1 and ED1A3 noted that careful attention to staff recruitment, training, and development was critical to delivering quality service and in a timely manner. This theme echoes the results obtained by Coussement
(2014), who found that product knowledge increases salesperson confidence and proficiency in delivering quality and prompt service. Keisidou et al. (2013) also showed that quality service provided timely requires significant employee input.

The participants also provided insights about ways they ensured quality service to satisfy Generation $Y$ customers. All three participants identified adherence to internal service level standards and controls, employee empowerment, and customer feedback as methods to ensure service quality. ED1A3 stated that to ensure quality service, they invested in simplifying some internal procedures to provide efficient operations, set minimum turnaround time for processes, and reviewed customer feedback daily. ED1A2 stated that they empowered the supervisors to act as quality control officers and to enforce compliance. ED1A1 noted that the organization focused on employee quality, and encouraged entrepreneurial behavior among employees in responding to customer feedback. ED1A1 further stated that apart from using quality control metrics to ensure the products and services were of acceptable standards, reemphasizing the organization's commitment to quality service to customers assisted in boosting customer satisfaction. The participants' assertions concur with the findings of Matthews et al. (2014), who concluded that the requirements for companies to sustain quality service include (a) open communication with their clients, (b) employee empowerment, and (c) employing competent and qualified personnel.

The participants explained that quality service and timely delivery resulted in more customer referrals and sales from satisfied Generation $Y$ customers. The evidence of positive peer reviews producing increased patronage aligns with the findings of Ziqiong et al. (2013), who showed satisfied customers provide positive wordof-mouth referrals, and repeat future purchases, which leads to increased future revenue of the business. ED1A3 explained that the simplification of their products and ease of accessing the products through Facebook enhanced service delivery, which boosted customer acquisition and retention. This explanation echoes findings of Hosseini et al. (2013), who discovered service quality affects customer satisfaction and sales, and with CSMS theory wherein increasing new product credibility impacts customer satisfaction and business improvement (Kobylanski and Pawlowska, 2012).

\section{Policy implications}

The inability of some business leaders in Nigeria to retain Generation $Y$ customers has resulted in a loss of revenue, which may affect the profitability of the business, low potential for employment opportunities, and negative impact on the society (Adebayo, 2013). The 
purpose of this qualitative multiple case study was to explore the customer satisfaction strategies business leaders use to retain Generation $Y$ customers. Understanding how leaders in the service industry have used customer satisfaction strategies to retain Generation $\mathrm{Y}$ customers may help other business leaders develop a competitive advantage for long-term sustainability. Organizations with a large pool of satisfied and loyal customers tend to have a lower cost of acquiring and maintaining customers, enjoy free referrals, and are more likely to sustain their profitability over a more extended period (Costanza and Finkelstein, 2015).

Apart from job security for employees, which is a direct result of the profitability of businesses, improvement in profitability also creates employment opportunities for more people, and in turn, an enhanced standard of living (Adebayo, 2013). Profitable businesses can contribute to building the communities and society in a variety of ways because profitable enterprises are more willing to participate in social responsibilities such as donating to local schools and charities, and serving in community organizations (Weber et al., 2014). Successful businesses also pay various tax remittances to the local, state and federal governments, which could enable government entities to improve public infrastructures for the benefit of the larger community (Heinonen, 2014).

\section{Conclusion}

Previous researchers found a positive relationship between service quality (Choudhury, 2014), customer satisfaction (Kaura, 2013), customer loyalty (Chodzaza and Gombachika, 2013), and firm performance (Choudhury, 2014). However, few have focused on Generation $Y$ customers despite the robust economic potentials of this cohort. Using a calculated approach to customer satisfaction that incorporates continuous improvement for businesses is an essential consideration in the CSMS theory (Alvarez-Garcia et al., 2017; Kobylanski and Pawlowska, 2012). However, the effectiveness of customer satisfaction strategies to retaining Generation Y customers for long-term business sustainability is not clear (Gizaw and Pagidimarri, 2014).

The findings from this qualitative multiple case study revealed that positive brand image, social media, continuous engagement, feedback, co-creation, quality service and timely delivery all improved the retention of Generation $Y$ customers. Using data collected from leaders in the banking, entertainment, and hospitality industry in Nigeria and document review, we found that business leaders need to enhance the satisfaction of Generation $Y$ customers to improve customer retention, and in turn, competitive advantage. The findings of this study also underscore prior research findings that branding, engagement, feedback, and co-creation are emerging areas for building customer satisfaction strategies (Kandampully et al., 2015). Effective customer satisfaction strategies may lead to increased loyalty, sustained profitability, and improved firm reputation (Abram et al., 2014). However, business leaders should also realize that customer satisfaction strategies are not sacrosanct; they are dynamic tools shaped by a combination of an organization's internal processes, the macroeconomic environment, and customer changing behavior especially for the fast-growing generational cohort in Nigeria.

\section{Recommendations}

Customer satisfaction and retention are crucial because of the several implications for businesses, employees, and communities (Chuah et al., 2017). We have three recommendations for action.

The first recommendation is that leaders periodically evaluate, through continuous interaction with Generation $Y$ customers, how their organization's systems and procedures are organized to guarantee quality service and timely delivery. This is because Generation $Y$ customers can be spontaneous in abandoning any product or service. The study findings indicated business leaders who periodically evaluate their organization's system and processes to ensure quality service and timely delivery experience more satisfied customers, and increased company revenue.

Second, leaders should devise clear strategies to build trust and win the loyalty of Generation $Y$ customers. The study findings showed that business leaders using robust strategies to continuously engage customers are better at understanding, managing and anticipating the needs of Generation Y customers.

The third recommendation is for business leaders to develop an entrepreneurial mindset in designing their unique customer satisfaction strategies for the dynamic marketplace. For instance, companies operating in Nigeria may invest in providing free internet access in strategic offices or hubs to encourage interaction with Generation Y customers.

The study findings revealed a situational context within the customer satisfaction strategies such that merely copying the strategy used by a company in an industry may not suffice. Business leaders should identify their unique strengths or competitive advantage that would enhance their customer satisfaction strategies. Researchers interested in advancing this study can pursue a quantitative examination of the influence of each customer satisfaction strategy identified from this study on the retention of Generation Y customers.

\section{CONFLICT OF INTERESTS}

The authors have not declared any conflict of interests. 


\section{REFERENCES}

Abram M, Picard L, Navarro B, Piolino P (2014). Mechanisms of remembering the past and imagining the future: New data from autobiographical memory tasks in a lifespan approach. Consciousness and Cognition 29(1):76-89.

Adebayo $O$ (2013). Nigeria industrial and university education entrepreneurial experience. International Journal of Science and Research 2:460-468.

Alvarez-Garcia J, Rio-Rama MC, Simonetti B (2017). Quality management and customer results; The tourist accommodation sector in Spain. International Journal of Quality and Reliability Management 34:701-719.

Amin M (2016). Internet banking service quality and its implication on ecustomer satisfaction and e-customer loyalty. International Journal of Bank Marketing 34:280-306.

Anselmsson J, Bondesson NV, Johansson U (2014). Brand image and customers willingness to pay a price premium for good brand. Journal of Product and Brand Management 23:90-102.

Arnaboldi M, Azzone G, Sidorova Y (2017). Governing social media: The emergence of hybridized boundary objects. Accounting, Auditing and Accountability Journal 30:821-849.

Ashley C, Tuten T (2015). Creative strategies in social media marketing: An exploratory study of branded social content and consumer engagement. Psychology and Marketing 32(1):15-27.

Bilgihan A (2016). Gen Y customer loyalty in online shopping: An integrated model of trust, user experience and branding. Computers in Human Behavior 61:103-113.

Bolton R, Parasuraman A, Hoefnagels A, Migchels N, Kabadayi S, Gruber T, Solnet D (2013). Understanding Generation $Y$ and their use of social media: A review and research agenda. Journal of Service Management 24:245-267.

Bowen JT, Chen McCain SL (2015). Transitioning loyalty programs: A commentary on "the relationship between customer loyalty and customer satisfaction." International Journal of Contemporary Hospitality Management 27:415-430.

Brodie R, Hollebeek L, Juric B, llic A (2011). Customer engagement: Conceptual domain, fundamental propositions, and implications for research. Journal of Service Research 14:252-271.

Celuch K, Robinson NM, Walsh AM (2015). A framework for encouraging retail feedback. Journal of Service Marketing 29:280292.

Chen $H$, Chang $Y$, Chang $H$ (2016). A numerical definition-based systematic design approach for coupling consumers image perception with product form. Journal of Engineering, Design and Technology 14:134-159.

Chinomona R (2016). Brand communication, brand image and brand trust as antecedent of brand loyalty in Gauteng province of South Africa. Africa Journal of Economic and Management 7:124-139.

Chodzaza GE, Gombachika HSH (2013). Service quality, customer satisfaction and loyalty among industrial customers of a public electricity utility in Malawi. International Journal of Energy Sector Management 7:269-282.

Choudhury K (2014). Service quality and word of mouth: A study of the banking sector. International Journal of Bank Marketing 32:612-627.

Chuah SHW, Marimuthu M, Kandampully J, Bilgihan A (2017). What drives Gen $Y$ loyalty? Understanding the mediated moderating roles of switching costs and alternative attractiveness in the valuesatisfaction-loyalty chain. Journal of Retailing and Consumer Services 36:124-136.

Costanza DP, Finkelstein LM (2015). Generationally based differences in the workplace: Is there a there there? Industrial and Organizational Psychology 8:308-323.

Coussement K. (2014). Improving customer retention management through cost-sensitive learning. European Journal of Marketing 48:477-495.

Counted AV, Arawole JO (2015). 'We are connected, but constrained': internet inequality and the challenges of millennials in Africa as actors in innovation. Journal of Innovation and Entrepreneurship 5(1):1-21.

Debevec K, Schewe CD, Madden TJ, Diamond WD (2013). Are today's
Millennials splintering into a new generational cohort: Millennials splintering into a new cohort. Journal of Consumer Behaviour 12(1):20-31.

Donnelly C, Scaff R (2013). Who are the Millennial shoppers? And what do they really want? Accenture Outlook 2:1-7.

Floreddu PB, Cabiddu F (2016). Social media communication strategies. Journal of Services Marketing 30:490-503.

Gizaw KD, Pagidimarri V (2014). The mediation effect of customer satisfaction on service quality - customer loyalty link in insurance sector of Ethiopia: A study. International Journal of Marketing and Technology 4(1):184-199.

Guillet BD, Kucukusta D (2016). Spa market segmentation according to customer preference. International Journal of Contemporary Hospitality Management 28:418-434.

Harwood T, Garry T (2015). An investigation into gamification as a customer engagement experience environment. Journal of Services Marketing 29:533-546.

Heinonen K (2014). Multiple perspectives on customer relationships. International Journal of Bank Marketing 32:450-456.

Hosseini SY, Zadeh MB, Bideh AZ (2013). Providing a multidimensional measurement model for assessing mobile telecommunication service quality (MS-qual). Iranian Journal of Management Studies 6:7-29.

Jaakkola E, Alexander M (2014). The role of customer engagement behavior in value co-creation: A service system perspective. Journal of Service Research 17:247-261.

Kandampully J, Zhang T, Bilgihan A (2015). Customer loyalty: A review and future directions with a special focus on the hospitality industry. International Journal of Contemporary Hospitality Management 27:379-414.

Kaura V (2013). Service convenience, customer satisfaction, and customer loyalty: Study of Indian commercial banks. Journal of Global Marketing 26(1):18-27.

Keisidou E, Sarigiannidis L, Maditinos D, Thalassinos IE (2013). Customer satisfaction, loyalty and financial performance: A holistic approach of the Greek banking sector in marketing intelligence and planning. International Journal for Bank Marketing 31:259-288.

Kobylanski A, Pawlowska B (2012). Managing customer satisfaction: A conceptual framework. The Business Review Cambridge 20:33-41.

Kolawole M (2017). Internet Access in Nigeria: Mobile Phones, Issues, and Millennials. Journal of Pan African Studies 10(10):153.

Lissitsa S, Kol O (2016). Generation X vs. Generation Y: A decade of online shopping. Journal of Retailing and Consumer Services 31:304312.

Maslowska E, Malthouse EC, Collinger T (2016). The customer engagement ecosystem. Journal of Marketing Management 32:469501.

Matthews DR, Son J, Watchravesringkan K (2014). An exploration of brand equity antecedents concerning brand loyalty: A cognitive, affective, and conative perspective. Journal of Business and Retail Management Research 9:26-39.

Melnyk V (2014). Resisting temptation: gender differences in customer loyalty in the presence of a more attractive alternative. Australasian Marketing Journal 22:335-341.

Melnyk V, Bijmolt T (2015). The effects of introducing and terminating loyalty programs. European Journal of Marketing 49:398-419.

Munari L, Lelasi F, Bajetta L (2013). Customer satisfaction management in Italian banks. Qualitative Research in Financial Markets 5:139-160.

Naumann K, Bowden JL, Gabbott M (2017). Exploring customer engagement valences in the social services. Asia Pacific Journal of Marketing and Logistics 29:890-912.

Ordun G (2015). Millennial (Gen Y) consumer behavior their shopping preferences and perceptual maps associated with brand loyalty. Canadian Social Science 11(4):40-55.

Parment A (2013). Generation Y vs. baby boomers: Shopping behavior, buyer involvement and implications for retailing. Journal of Retailing and Consumer Services 20:189-199.

Preikschas MW, Cabanelas P, Rudiger K, Lampon JF (2017). Value cocreation, dynamic capabilities and customer retention in industria markets. Journal of Business and Industrial Marketing 32:409-420.

Price RA, Wrigley C, Straker K (2015). Not just what they want, but why 
they want it: Traditional market research to deep customer insights. Qualitative Market Research: An International Journal 18:230-248.

Rossetto KR (2014). Qualitative research interviews: Assessing the therapeutic value and challenges. Journal of Social and Personal Relationships 31:482-489.

Saaksjarui M, Hellen K, Balabanis G (2016). Sometimes a celebrity holding a negative public image is the best product endorser. European Journal of Marketing 50:421-441.

Sasmita J, Suki NM (2015). Young consumers' insights on brand equity. Effects of brand association, brand loyalty, brand awareness, and brand image. International Journal of Retail and Distribution Management 43:276-292.

Schewe CD, Debevec K, Madden TJ, Diamond WD, Parment A, Murphy A (2013). If you've seen one, you've seen them all!" Are young millennials the same worldwide? Journal of International Consumer Marketing 25(1):3-15.

Straker K, Wrigley C (2016). Designing an emotional strategy: Strengthening digital channel engagements. Business Horizons 59:339-346.

Toldos-Romero M, Orozco-Gómez MM (2015). Brand personality and purchase intention. European Business Review 27:462-476.
Tsimonis G, Dimitriadis S (2014). Brand strategies in social media. Marketing Intelligence and Planning 32:328-344.

Verleye K, Gemmel P, Rangarajan D (2016). Engaged customers as job resources or demands for frontline employees? Journal of Service Theory and Practice 26:363-383.

Weber O, Diaz M, Schwegler R (2014). Corporate social responsibility of the financial sector: Strengths, weaknesses and the impact on sustainable development. Sustainable Development 22:321-335.

Wepener M, Boshoff C (2015). An instrument to measure the customer based corporate reputation of large service organizations. Journal of Services Marketing 29:163-172.

Xie KL, Chen CC (2013). Progress in loyalty program research: Facts, debates, and future research. Journal of Hospitality Marketing and Management 22:463-489.

Yin RK (2014). Case study research: Design and methods (5th ed.). Thousand Oaks, CA: Sage.

Ziqiong Z, Zili Z, Rob L (2013). Regional effect on customer satisfaction with restaurants. International Journal of Contemporary Hospitality Management 25:705-722. 